\title{
Collaborative, Multi-perspective Historical Writing: The Explanatory Power of a Dialogical Framework
}

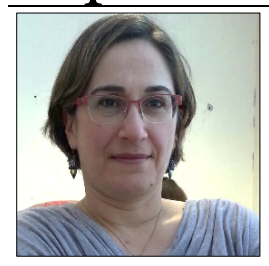

\author{
Yifat Ben-David Kolikant \\ Hebrew University, Jerusalem, \\ Israel
}

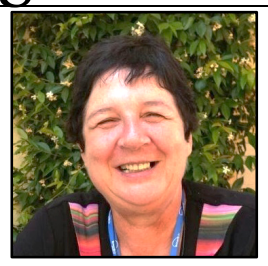

Sarah Pollack

Weizmann Institute of Science, Israel

\begin{abstract}
There is an increased interest within the history education community in introducing students to the multi-perspective and interpretative nature of history. When these educational goals are pursued within collaborative contexts, what are the relationships of individuals from conflicting groups with historical accounts that they produced as a group? How does the joint writing influence their historical understanding? We analyzed the joint accounts produced by high-school Israeli students, Jews and Arab/Palestinians, who collaboratively investigated historical events related to the IsraeliPalestinian conflict. Employing a thematic analysis and a Bakhtinian-inspired discourse analysis, we found that the joint texts were constructed of themes from both in-groups' perspectives. The students constructed a dialogic relationship between these themes, which enabled them to legitimize the other's voice, yet keep the voices unmerged. Additionally, although they never abandoned their in-group narratives, the joint account reflected a new, multi-perspective historical meaning of the historical event.
\end{abstract}

Yifat Ben-David Kolikant is an associate professor in the Seymour Fox School of Education at the Hebrew University of Jerusalem. Dr. Ben-David Kolikant's research focuses on examining the tripartite relationship of students, school learning, and technology in the information era. Mainly, her research revolves around two inter-related questions: (1) How does students' knowledge of subjects outside of school impact on their school learning? And, (2) what pedagogies are suited to the information age and the needs of students and what role does technology play? Dr. Ben-David Kolikant holds a Ph.D. degree in science teaching from the Weizmann Institute of Science, received in 2002.

Sarah Pollack received her PhD from the Hebrew University of Jerusalem, Israel. Her research interests focus on understanding learning processes in an ethno-politically based environment in order to devise an instructional model suitable in an age of pluralism, multiculturalism, and digitalism.

$\cos 0380$

\section{Introduction}

Within the history education community, interest in introducing students to the multi-perspective and interpretative nature of history is growing. It is thought that exposing students to multiple perspectives while engaging them in historians' thinking habits will encourage and facilitate them to develop critical thinking and communication skills. Consequently, this would enable them to better function in a multicultural and globalized society (McCully, 2012; Stradling, 2003; also see http://www.euroclio.eu). 
One way to practice multi-perspectiveness in a history classroom is through collaborative contexts. Often, these contexts can be characterized as hetero-agent and hetero-narrative (HAHN). Hetero-narrative, in the context of history education, refers to students encountering different, even contradicting narratives and interpretations of a historical event. Hetero-agent refers to cases in which students from different cultural, national or ethnic backgrounds, i.e., holding different narratives, collaborate. In these HAHN contexts, when students produce a joint account, as part of their collaborative assignment, an intriguing question is what are the relationships between group products and individuals' historical understanding of the event?

In order to address this question, we analyzed the joint texts produced by high-school Israeli students, Jews and Arabs/Palestinians (the latter are also referred to as Arabs or Palestinians) who were engaged in an investigation of a historical event related to the Israeli-Palestinian conflict, by analyzing primary and secondary sources, and producing a joint account.

Exploring the relationships between group products and individual knowledge is relevant to the broad community of (computer-supported) collaborative learning and is especially challenging in the Humanities, which require a narrative mode of thought that seeks to explain the storied meaning people make of these relationships (Bruner, 1986). In history, for example, it is possible that two experienced historians, working with the same source materials and using the same methods, might reach different yet legitimate and reasonable interpretations of the same past events (Wertsch \& Poleman, 2001); this is even more likely to occur with students from different ethnic backgrounds, as evident in the literature review below.

\section{Literature review}

\section{The mastery/appropriation theoretical framework}

Sociocultural theories underscore that thinking, like any human action, is mediated by what Wertsch (1998) terms "cultural tools." Historical narratives are such cultural tools because they mediate our thinking about the past and are thus crucial in constituting individual and group ethnic and national identities. Historical narratives are, in essence, far from being neutral; rather, they reflect the viewpoints of particular historical narrators and producers (Burke, 1969).

Wertsch (1998) suggests a bi-dimensional theoretical framework to articulate the interaction of agents with historical presentations: (a) a cognitive dimension, or the mastering (knowing how) of a presentation; and (b) an affective dimension related to one's identity and sense of belonging, which promotes either the appropriation of a presentation (making the presentation one's own) or resistance of it. Wertsch claims that one's interaction with a historical presentation varies regarding both dimensions, depending on many variables, such as particular socio-political contexts and interlocutors.

Wertsch's framework is powerful in explaining situations in which a bias exists in students' interactions with historical presentations, caused by their appropriation of the in-group narrative, or, conversely, their resistance to out-group narratives (Wertsch, 2000). For example, individuals often accept whatever supports their beliefs but meticulously examine and critique anything that contradicts them (e.g., Chambliss \& Garner, 1996; Kuhn \& Udell, 2007; Porat, 2004). Similarly, in multi-cultural societies, students from minority groups may face difficulties when they are taught the majority's hegemonic narrative, because they resist it . They might, for example, be required to accept the narrative as correct, and be evaluated as ignorant or worse, immoral, if disagree with it. (e.g., Almarza, 2001; Barton \& Levstik, 1998; Epstein, 1998, 2000). In collaborative settings, Wertsch' framework is useful for articulating situations when one group 
assimilates the narrative of the other group, as described, for example, by Goldberg, Schwarz \& Porat (2011). This framework is also useful in situations in which groups clash, when they fail to write collaboratively, because of the appropriation/resistance of the in-/out- group narrative (e.g., Prime project, Bar-On \& Adwan, 2006).

However, Barton and McCully $(2010,2012)$, who studied the impact of the Northern Irish history curriculum on Irish students, claim that students' interactions with the in- and out-group narrative were beyond the mastery/appropriation framework. This curriculum aims at presenting two narratives of events in Irish history: the Catholic and the Protestant viewpoints. Barton and McCully interviewed students from both groups who studied history according to this curriculum, albeit not in a hetero-agent collaborative context. They found that students did not abandon their in-group's narrative; however, they displayed a more complex understanding of the nature of Irish history and developed a tendency to pursue the "other" perspective of a historical event they had encountered.

In a previous work, we investigated the interactions within 26 bi-ethnic groups comprising Israeli Jews and Israeli Palestinian/Arabs who collaboratively investigated events related to the history of IsraeliPalestinian conflict. As expected, the analysis of the essays, which they wrote pre- their e-discussion with their peers, revealed that the Jewish and Arab students have conflicting viewpoints about the event. In the analysis of the online discussions we found that most of the discussions (85\%) were disputatious. The students metaphorically "hit" each other, looking for flaws in each other's narrative. Wertsch's framework provided as useful explanation: students appropriated their in-group narratives and resisted the other narrative.

In $62 \%$ of the groups (namely 16 groups), however, these hits brought about intersubjective moments. Specifically, participants re-evaluated their initial position as a result of a "successful hit". We termed this process "fission" in order to emphasize that the students did not converge into one unified voice, but rather, became enriched by means of the other's voice (omitted, 2015). Except for one, all these groups produced a group account with a historical presentation that was agreed upon by all group members. Wertsch's framework is insufficient to provide insights on the relationships between the heterogeneous agents and the joint text composed in HAHN situation, which is the aim of this study. It is unlikely that these students were persuaded to assimilate (or appropriate) the narrative of the other side. Nonetheless, these joint presentations reflected a change in both students' appropriation and resistance of the two presentations, what made it difficult to articulate students' perceptions of the historical event. The work by Barton and McCully $(2010,2012)$ sheds light on the limitation of Wertsch's framework, but does not provide insights as to HAHN situations. In their study, students did not work in a collaborative context, let alone produced a joint historical account. We believe that Bakhtin dialogical stance is useful to articulate the relationships between the heterogeneous agents and the joint text composed in HAHN situation, as we now turn to explain.

\section{The Dialogical Theory: A Coherent Theoretical Framework to Articulate Collaboration?}

According to Bakhtin (1981), our entire being exists in a continuous dialogue with the surrounding world. We each have a voice, composed of ideas, viewpoints, knowledge, beliefs, concerns, and so forth (Wertsch, 1998). In each utterance produced, however, we use words that have existed previously "in other people's mouths, in other people's contexts, serving other people's intentions, namely we use other people's voices. It is from there that one must take the word, and make it one's own" (Bakhtin, 1981, p.294). Therefore, each utterance entails at least two voices, that of the speaker (to whom utterances are attributed) and that of the addressee, who understands (i.e. populates) it with his or her voice. Accordingly, meanings emerge within the boundaries of (at least) two voices. This conceptualization of learning and meaning- 
making focuses on the learner's agency, in a way that is missing in traditional behavioral and cognitive accounts of learning (Koschmann, 1999; Matusov, 2009). It captures simultaneously the evolution of knowledge of the individual and the group, as each voice is created and changed in response to other voices. Furthermore, this theoretical perspective acknowledges the plurality of unmerged voices in the world; that is, even if voices agree, they might "do so from different perspectives and different senses of the world" (Morson \& Emerson, 1990, p. 237).

Inspired by Bakhtin (1981) and Hermans (2001), we suggest viewing individual knowledge as a social entity: one's knowledge (or voice) is constituted by voices and utterances living in one's mind that have diversified dialogic relations among them.

Morson and Emmerson (1990), in their interpretation of Bakhtin, distinguish between two types senses of truth (or relations of a person with a voice): monologic and dialogic. In a monologic sense of truth, the truthfulness of a claim is judged independently from its author(s), and is repeatable by others, i.e. assumed to be universal. For example, once a mathematical theorem is proved, one can use it as truth, to solve and prove other theorems. Historians, however, like other many researchers in the Humanities are often guided by a dialogic sense of truth, which considers truth as the result of what Bakhtin (1984) terms "voice-ideas", that is, "the idea that represents a person's integral point of view on the world, which cannot be abstracted from the person voicing it" (Morson and Emmerson, 1990: 237). Matusov and Von Duyke (2010) explain that understanding the truth of an idea also means "to find out the limitations of the idea and the limitations of the self as having a vested ontological interest in the truth, something which is impossible to do without help of others" (p. 177).

A monologic sense of truth echoes Wertsch's framework: one masters the utterance and either perceives it as truth or not, namely appropriates it as its own, or resist it. A dialogic sense of truth describes a relationship with an utterance which is beyond mere mastery, yet is not captured by appropriation and resistance and therefore, seemed useful to examine students' relationships with joint and individual historical presentation in HAHN environments.

\section{Research Questions}

We posed the following research questions: What historical perspective(s) is(are) manifested in the joint essay? What are the relationships between the historical perspective manifested in the joint text and the participants' perspectives on the event? How did the participants interact with the in- and out- group narratives and how this interaction enabled the production of a joint text?

\section{Methods}

\section{Israel: the macro context of the study}

Our study was conducted in Israel, where the Jews constitute the majority and the Arabs, who comprise about $20 \%$ percent of the Israeli population, make up the largest minority. The Israeli Arabs are citizens of Israel. They are also descendants of the Palestinians who were the majority in the territory during the British mandate (1917-1948). As such, their sense of belongingness to the Israeli and the Palestinian groups, which are in a conflict, is complicated (Salomon \& Issawi, 2009). In this paper, we use the terms Palestinians and Arabs interchangeably.

Jewish and Arab students usually study in different schools. In many domains (e.g., math and science), their curricula fully overlap. The history curricula, on the other hand, overlap only partially. In the Jewish sector, certain topics are studied in more depth than in the Arab sector (e.g., the period of the 
Second Temple in Jerusalem) and vice versa (e.g., the history of Islam). Podeh (2010), who reviewed the changes in Israeli history curricula and history textbooks between 2000 and 2010, claims that although the curricula have improved in recent years and now present a more balanced account of events regarding the Arab-Israeli conflict, the history classrooms are still characterized by univocality. Namely, the history textbooks do not contain negative stereotypes and images of the other, yet students are exposed to one narrative.

\section{The experiment}

We engaged Israeli Jewish students and Israeli Palestinian/ Arab students in a collaborative activity. They were asked to investigate an event relevant to the joint troubled past of their in-groups (the Israeli-Palestinian conflict), using historical texts that presented at least two perspectives on the event.

The event studied was Britain's issuance of the Churchill White Paper in 1922. The British explained in the text of Churchill's White Paper that they wanted to settle "[t]he tension, which [had] prevailed from time to time in Palestine". The assignment questions were as follows: What did the British promise to the Arabs and the Jews in the White Paper of 1922? How did both sides (Arabs and Jews) respond to this document, and why? Why is the White Paper significant for the British?

This event, the issuance of the Churchill White Paper (like many others) is described differently in the Palestinian and the Zionist (Israeli national) narratives. From a Palestinian viewpoint, this event is part of the process that led to the Nakba (meaning, the catastrophe), the expulsion of the Palestinians in 1948 from the land on which they had lived for centuries. From an Israeli viewpoint, this event is part of the Jewish struggle for Revival (Tekumah), i.e., returning to their fatherland after 2000 years of exile and oppression.

The activity is bi-phasic. In the first phase, students worked in ethnically homogenous pairs, Jewish pairs (JPs) and Arab or Palestinian pairs (APs). They were asked to read all the sources and upload their answers to the assignment questions to a wiki environment. In the second phase, bi-ethnic groups were formed, each comprising two ethnically homogenous pairs. They read each other's answers, commented on them, and then conduct a synchronous online chat (we will refer to it as e-discussion). They were instructed to either write a joint consensual presentation of the event, or alternatively present all members' perspectives and discuss and explain the essence of their differences. For a more detailed description of the instructional model and its design rationale, see Pollack and Ben-David Kolikant (2011).

\section{Participants}

The participants of this study comprised 15 groups (total of 60 students), each consisting of Palestinian and Jewish students, who underwent fission in the e-discussions, and produced a joint essay. They all studied in selective schools whose achievements in matriculation exams are above the national average.

\section{Data sources}

Data sources for this study included the pairs' essays produced in the first homogenous phase and the joint essays produced in the second phase by the groups, as uploaded to the wiki. 


\section{Methods of analysis}

Thematic Analysis

The focus of our thematic analysis (Braun \& Clarke, 2006) was on students' historical understanding of the event. To this end, we identified the historical agents to which students attributed an active role in the event discussed, the role attributed to each agent, the constraints, circumstances and beliefs upon which the agent is perceived to have acted, and the perceived relations between this agent and other agents (Seixas 1993; Peck et al., 2005; Peck, Poyntz, \& Seixas, 2011). Additionally, moral judgment was determined based on students 'use of expressions indicating a positive or negative opinion regarding the historical agents' actions. Themes, thus, revolved around the students' perceptions of the three major historical agents: British, Arab (i.e., Palestinian), and Jewish.

For example, the following excerpt is taken from an AP's essay:

This decision brought about a wave of protest of Palestinian Arabs against the British policy. In this Paper, the British broke their promises to the Arabs like they had done before in the Balfour Declaration and the Sykes-Picot Agreement. In 1922 the Arabs woke up and noticed that and protested against the British and the Jews.

In our analysis, the main actor in the AP's essay is the Arab historical agent, who protested at face of harsh circumstances, which are that the British historical agent "broke the promises" to the Arab historical agent. The "promises" probably refer to the Husayn-McMahon correspondences (1915-1916), in which the British agreed to recognize Arab's independence (See omitted, 2009, for further details). The historical theme we extracted is that of injustice. The Arab historical agent is portrayed as struggling. Often it was also portrayed as weak (i.e. facing constraints), relatively to the Jewish and the British historical agent. The theme of injustice is common in pair essays produced by Arab pairs.

The same historical agents are presented differently, by as JP as demonstrated in the following excerpt:

The White Paper settled the unrest and uncertainty. The Arabs were concerned that Eretz Israel would become entirely Jewish, which would bring the loss of the Arab culture and language in Eretz Israel, due to a mis-interpretation of the Balfour Declaration. The White Paper settled their concerns by ensuring that the intention in the Declaration is not to turn the entire Eretz Israel to the Jews, but rather a Jewish home would be established within the areas of Eretz Israel.

The Arab historical agent is portrayed as having mis-interpretations of the situation and a sense of uncertainty, to which the main actor, the British historical agent reacted: The British historical agent is portrayed positively, as fair, their policy is implied to be balanced, though misinterpreted.

Discourse analysis

In our discourse analysis we relied on Bakhtin's (1981) theoretical idea that we utter our voice (ideas, worldview, and so forth) using words and utterances previously uttered by other people, serving other voices, and populate them with our intentions, taking into account the audience of this utterance. Hence, every utterance is multi-voiced (since it serves simultaneously at least the voices of the speaker and the listeners, sometimes with different and even contradicting intentions and goals). We were inspired 
by Bakhtin's notion of double-voicedness in one's discourse: "in one discourse, two semantic intentions appear, two voices" (Bakhtin 1984, p. 189). Sometimes such a discourse enables one to produce a polyphony of multiple voices, when the voices do not merge into a single perspective, but rather, each of these voices has its own perspective, its own validity, and its own narrative weight within the speakers' discourse. In addition, other interactions between the voices are also possible.

First, we divided the texts into utterances, where an utterance includes a description of a historical agent, and often, its relationship with other historical agent(s). Then we identified the voices that the students integrated into their utterances. To this end, we compared phrases in their answers to the texts they were provided in the assignment (e.g., the primary and secondary sources, textbooks, and the Zionist and Palestinian narratives), public discourse (news), and text they had produced during the activity. Finally, we examined the ways students integrated these voices into their answer (i.e. change of wording (for example, past tense changed to future tense), adding or omitting qualifiers (e.g., "perhaps", "!!!") and markers (e.g., "the Arabs thought that").

This enabled us to identify the relationships between the voices used by the students and the meaning it conveyed. Specifically, we used the Bakhtin-inspired typology of Kamberelis and Scott (1992), comprising 6 possible interactions between voices. The two most relevant interaction types for this work are adoption and hidden polemic. Adoption is when one uses the other's words and blurs the borders between his or her voice and the other (metaphorically, these voices are melted into one). Hidden polemic refers to cases when users' use of words (previously used by another voice) influences the original goal of the original speaker, thereby expressing the user's disagreement or it introduces tension with the original goal of the utterance. The other interaction types are quoted, stylized, parodistic, and idealized) This analysis also enabled us to detect any expression of moral judgments vis-à-vis the historical agents.

The analysis of these texts was carried out separately by three researchers (two Jewish and one Arab). Disagreements among researchers regarding segmentation or categorization were resolved through discussions until a consensus was reached.

\section{Results}

\section{From dichotomy to multi-faceted historical perspectives}

The influence of students' ethnic identity was prominent in the ethnically homogenous pair essays that students produced in the first phase of the activity. The thematic analysis revealed that although all the students received the same sources and the same assignment, the pairs decided to integrate into their essays themes that were aligned with their in-group narrative and ignore or reject those that were aligned with the Other group's narrative. In fact, we observed a dichotomy in the historical presentations. For example, most of the APs (94\%, in comparison with $14 \%$ of the JPs) portrayed the Palestinian historical agent as the victim, as having national aspirations and legitimate rights to the land. This viewpoint was reflected in phrased like "the Arabs were deceived", "their lands were taken from them", "the Arabs thought that the White paper discriminated between them and the Jews as they are the local residents [and hence are legal owners of the land]. In contrast, most of the JPs (87\%, in comparison with $7 \%$ of the AP) portrayed the Arab historical agent as not pragmatic and unwilling to compromise and share the land with the Jews, as demonstrated in the following excerpt, which is taken from an essay of a JP "they [Arabs] did not agreed to share", "the appeasement policy of the British led the Arabs to believe that by means of violence they would gain political achievements". 
Additionally, about $40 \%$ of the AP (in comparison with $7 \%$ of the JP) mentioned the British proZionist, discriminative policy, stemming from their interest to rule in the area, often, employing negative moral judgment vis-à-vis the British historical agent, who "deceived", "tried to bypass the Arabs", "laughed at the Arabs", "made promises that they could have barely fulfilled", "broke off promises", "discriminated against", and was "unfair." In contrast, most JPs (67\% in comparison with $20 \%$ of the APs) portrayed the British as promoting a balanced policy towards the Jews and the Arabs, for example "a wise and moderate policy", and an "overt attempt to try to create equality between the various nationalities in the country".

The joint essays were composed from the same themes. Moreover, all joint essays included themes taken from the essays of both pairs. This is reflected in the frequency of each theme in the groups' essays, which were found to be in the range of its frequency among the JPs and the APs. For example, the frequency of the theme of unjust towards the Arab historical agent appears in $47 \%$ of the groups' essays, in comparison to $14 \%$ and $94 \%$ of the JP's and AP's essays, respectively. This implies that the joint essays were multi-faceted, namely, that participants took into account both historical perspectives.

The joint essays: Hidden polemic interaction between conflicting voices

The discourse analysis enabled us to further explore the relationships between the two in-group perspectives within the joint essays, as well as the discursive mechanisms used in the text when the participants interacted with multiple voices. Here we introduce an example of text segments from one group essay and the matching segments from the pair's essays. The segments are presented in Table 1.

Table 1. The response of the Arab historical agent to the issuance of the White paper in 1922

\begin{tabular}{|l|l|l|}
\hline \multicolumn{1}{|c|}{ The AP's essay } & \multicolumn{1}{|c|}{ The JP's essay } & \multicolumn{1}{c|}{ The group essay } \\
\hline $\begin{array}{l}\text { The response of the Arab side } \\
\text { was negative. They were angry } \\
\text { because their lands were taken } \\
\text { from them. }\end{array}$ & $\begin{array}{l}\text { The Arab population did not agree } \\
\text { with the White Paper because they } \\
\text { interpreted in an exaggerated way } \\
\text { the promises made to the Jews in } \\
\text { the White Paper. }\end{array}$ & $\begin{array}{l}\text { The Arab population did not } \\
\text { agree with the White Paper } \\
\text { because it was perceived as } \\
\text { the beginning of a process } \\
\text { whereby their lands would be } \\
\text { taken [from them]. }\end{array}$ \\
\hline
\end{tabular}

The segments from the two pair essays demonstrate the dichotomy we described above. Each pair adopted their in-group narratives and hence their perceptions of the Arab historical agents differed. The AP's claim that 'lands were taken' aligns with the themes of unjustness and victimhood of the Arab historical agent. The JP ascription of 'exaggerated interpretation' to the Arab historical agent is derived from the perception that the Arabs could and should have shared the land (which in the first place did not belong to them and yet the Jews were pragmatic and willing to share). Both ignored the themes of the other narrative, thereby expressing their resistance.

In the group essay they came up with this utterance: "perceived it as the beginning of the process of taking their lands". Both JP's and AP's original voices are evident in this utterance, but are altered. The idea regarding taking lands resembles the AP's essay. However, the theme is altered, from past tense ('were taken') to future tense ('would be taken'). This phrase is concatenated to "the beginning of a process". The change of the original AP's text allows the JP to maintain a hidden polemic interaction with AP's original idea. "The beginning of the process" means that this agent still had time to change its destiny, which is compatible with the Zionist perspective that this agent was non-pragmatic, not willing to share. Putting the 
issue of taking land in the Arab historical agent's perception also helps the JP to express their disagreement with this idea.

Moreover, this text is compatible with both the Zionist and the Palestinian perspectives. Both AP and JP could agree with this text but for different reasons that are based on different world views or different narratives that they never abandoned. Specifically, the JP probably agreed because the essay reflects their worldview that the Arab historical agent had time and could have behaved differently, be more pragmatic about the land. The AP probably agreed because the theme that lands were (eventually) taken was legitimized to the extent it was included in the joint text.

Moreover, we believe that each pair was aware that the Other has a different, still non-refutable point of view, that students were not naïve and rather understand that the text can be read differently. Note that the AP do not mention anything about the end the of the process as they did in the pair essay and the JP do not mention the Jewish right on the land but rather give room to the Arab historical agent to think it is his lands that is going to be taken. Namely, both the JP and AP legitimize with this utterance the other's viewpoint, without abandoning their narratives.

Finally, the joint text reflects an improvement in students' historical understanding of the event. The combination of voices brings about a new meaning, a new reason for the Arabs' disagreement with the White paper, different from what was claimed by both AP and JP in their pair essays. This is reflected in the tangled relationship between the historical agents and their mutual impact on each other. Moreover, in the joint essay participants describe a historical process and avoid emotional empathy (as in AP's text) and moral judgment (as in JP's text) vis-à-vis the historical agents. Their ability and willing to allow the other's voice in the joint text reflects an understanding of the interpretive nature of history and it multiplicity.

\section{Discussion and conclusions}

Wertsch's (1998) two-dimensional framework of mastery and appropriation/resistance was useful in articulating the interaction of students with their in- and out- group narratives when producing the pairs' essays. Although all the students received the same sources and the same assignment, the pairs chose to integrate into their essays those themes that aligned with their in-group narrative and ignore those that aligned with the Other-group narrative. This result is consistent with the vast empirical work conducted on students' interactions with multiple historical representations (e.g., Chambliss \& Garner, 1996; Porat, 2004; Wertsch, 2000).

However, for articulating what happens in the joint essays, we needed to account for the transcendence of both initial in-group positions into a complex narrative with over and under-tones of voices that acknowledge each other, take each other seriously, and still do not merge, retaining their implied critique, as a potent charge in the newly produced group essay.

Specifically, in the joint essays - agreed upon by all group members and produced after a heated yet elaborative e-discussion (omitted, 2015) - the two contrasting perspectives neither disintegrated nor fused into one. Rather, these essays can be viewed as a mosaic of perspectives. They share several characteristics: (a) they are composed of bits of pre-existing (pairs') perspectives; (b) they are compatible with both the Zionist and Palestinian historical narratives; and yet (c) they create a whole new historical meaning regarding the historical agents' actions and the complex interests and constraints, in which they played a role. These characteristics are demonstrated above in one example. 
Thus, we found, Wertsch's framework to be of limited usefulness for articulating students' interaction with both in- and out- group narratives and historical presentations in collaborative context. The JP agreed to include a theme which originally appeared in the AP's pair essay and aligned with the Palestinian notion of victimhood. Yet they altered it, thereby introducing their resistance to it. Furthermore, the altered text aligns with their in-group narrative, namely their act is dominated by the appropriation of their in-group narrative.

Thus, the appropriation/resistance framework capture only part of the complicatedness of the relationship between students' voices, whereas the Bakhtinian-inspired analytical concept of doublevoicedness that preserves the relationships between the multiple opposing voices, enabled us to advance our understanding of the interaction of participants with different voices in this HAHN context. By utilizing the notion of double voiced discourse, we were able to recognize the hidden polemic interaction between the different voices in the text. This discursive interaction enabled the students to allow room for the other narrative (which they did not do in the in-group pair essays), and this in turn enabled the Other to agree to the joint text. At the same time, the JP and the AP phrased the text in a way that allowed both of them to maintain their disagreement, that is, to legitimize the voice of the other, and at the same time, to emphasize that their voices were not merged.

This joint text resembles Kelman's (2010) notion of "settlement" between groups in conflict, when texts produced jointly possess a "double construct", namely, each group can read it differently or live peacefully with it, although both are aware of the other's possible interpretation of it.

Finally, Wertsch's framework emphasizes that students' interaction with the historical presentations was still dominated by their appropriation and resistance of narratives. The Bakhtinian framework is more sensitive to the learning (transcendence of the original views) that took place. It emphasizes that students' interaction with the narratives and presentations changed, moving from monological, author-less sense of truth to a sense of dialogical, multiple voice ideas (Morson and Emerson, 1990). First, the work on producing the joint texts in the HAHN context provided students with an opportunity to recognize that language is not neutral, but rather, is ideological and heteroglot. Equally important, students' interaction with their in- and out-group voices in the joint texts is more dialogical than is their interaction with these voices in the pair essays.

This is in line with the goals of Humanities education. The main goals of Humanities education in general, and history education, in particular, is to humanize students, to assist them in re-examining how they perceive themselves and others, and to assist them in becoming aware of the limitations of their understanding of the world (Parker, 2006; Wineburg, 2001). Therefore, successful collaboration in the Humanities might lead to achieving a deeper understanding of the text and a better understanding of other people and their world view.

\section{References}

Almarza, D. J. (2001). Contexts shaping minority language students' perceptions of American history. Journal of Social Studies Research, 25(2), 4-22.

Bakhtin, M. (1981). The dialogical imagination: Four essays. (C. Emerson and M. Holquist, Trans.). Austin: University of Texas Press.

Bakhtin, M. M. (1984). Problems of Dostoevsky's Poetics. Edited and translated by Caryl Emerson. Minneapolis: University of Minnesota Press. 
Bar-On, D., \& Adwan, S. (2006). The PRIME shared history project. In Y. Iram (ed). Educating toward a culture of peace (pp. 309-323). Connecticut: IAP.

Barton, K., \& Levstik, L. (1998). "It wasn't a good part of history": National identity and students' explanations of historical significance. Teachers College Record, 99(3), 478-513.

Barton, K. C., \& McCully, A. W. (2010). "You can form your own point of view": Internally persuasive discourse in Northern Ireland students' encounters with history. Teachers College Record, 112(1), 142-181.

Braun, V., \& Clarke, V. (2006) Using thematic analysis in psychology. Qualitative Research in Psychology, 3(2). 77-101.

Bruner, J. (1986). Actual minds, possible worlds. Cambridge, MA: Harvard University Press.

Burke, K. (1969). A grammar of motives. Berkeley: University of California Press.

Epstein, T. (1998). Deconstructing differences in African-American and European-American adolescents' perspectives of U.S. History. Curriculum Inquiry, 28(4), 397-423.

Epstein, T. (2000). Adolescents' perspectives on racial diversity in US history: Case studies from an urban classroom. American Educational Research Journal, 37(1), 185-214.

Goldberg, T., Schwarz, B. B., \& Porat, D. (2011) Changes in narrative and argumentative writing by students discussing 'hot' historical issues. Cognition and Instruction, 29(2) 185-217

Kamberelis, G., \& Scott, K. D. (1992). Other people's voices: The coarticulation of texts and subjectivities. Linguistics and Education, 4(3-4), 359-403.

Kelman, H. C. (2010). Conflict resolution and reconciliation: A social-psychological perspective on ending violent conflict between identity groups. Landscapes of Violence, 1(1), article 5.

Koschmann, T. (1999). Toward a dialogic theory of learning: Bakhtin's contribution to understanding learning in settings of collaboration. International Society of the Learning Sciences, 38.

Kuhn, D., \& Udell, W. (2007). Coordinating own and other perspectives in argument. Thinking \& Reasoning, 13(2), 90-104.

Matusov, E. (2009). Journey into Dialogic Pedagogy. Hauppauge, NY: Nova Publishers.

Matusov, E., \& von Duyke, K. (2010). Bakhtin's notion of the Internally Persuasive Discourse in education: Internal to what? (A case of discussion of issues of foul language in teacher education). In K. Junefelt \& P. Nordin (Eds.), Proceedings from the Second International Interdisciplinary Conference on perspectives and limits of dialogism in Mikhail Bakhtin (pp. 174199). Stockholm: Stockholm University.

McCully, A., (2012). History teaching, conflict and the legacy of the past. Education, Citizenship and Social Justice, 7 (2). 145-159.

Morson, G. S., \& Emerson, C. (1990). Mikhail Bakhtin: Creation of a prosaics. Stanford University Press.

Parker, Walter C. Public discourses in schools: Purposes, problems, possibilities. Educational Researcher, 35(8), (2006), 11-18.

Peck, C., Poyntz, S. R., \& Seixas, P. (2011). 'Agency' in students' narratives of Canadian history. In D. Shemilt \& L. Perikleous (Eds.), What does it mean to think historically? Nicosia, Cyprus: Association for Historical Dialogue and Research. 
Podeh, E. (2010). Univocality within multivocality: The Israeli-Arab-Palestinian conflict as reflected in Israeli history textbooks, 2000-2010. Journal of Educational Media, Memory, and Society, 2(2), $46-62$.

Pollack, S. \& Ben-David Kolikant, Y. (2011). Fostering dialogue in a context of socio-political conflict: an instructional model. In J.E. White \& M. Peters, (Eds.) Bakhtinian pedagogy: Opportunities and challenges for research, policy and practice in education across the globe (pp. 129-148). NY: Peter Lang Publications.

Porat, D. (2004). 'It's Not Written Here, But This Is What Happened:' textbooks' and students formation of historical consciousness, American Educational Research Journal, 41 (4), 963-996.

Salomon, G., \& Issawi, M. (2009). The report of the public committee to define the state policy in field of education for a share life for Arabs and Jews. An executive summary was retrieved from: http://peach.haifa.ac.il/images/2/2b/English Executive Summary.doc

Seixas, P., \& Peck, C. (2004). Teaching historical thinking. In A. Sears \& I. Wright (Eds.), Challenges and prospects for Canadian social studies (pp. 109-117). Vancouver: Pacific Educational Press.

Stradling R. (2003). Multiperspectivity in history teaching : a guide for teachers, Strasbourg:Council of Europe.

Wertsch, J. V. (1998). Mind as action. NewYork NY: Oxford University Press.

Wertsch, J. (2000). Is it possible to teach beliefs, as well as knowledge about history? In P. Stearns, P. Seixas, \& S. Wineburg (Eds.), Knowing, teaching, and learning history (pp. 38-50). New York: New York University Press.

Wertsch, J.V., \& Polman., J.L. (2001). The intuitive mind and knowledge about history. In B. Torff \& R.J. Sternberg, Eds. Understanding and teaching the intuitive mind: Student and teacher learning, pp.57-72.

Wineburg, S. (2001). Historical thinking and other unnatural acts: Charting the future of teaching the past. Philadelphia: Temple University Press.

\section{(c)) EY}

New articles in this journal are licensed under a Creative Commons Attribution 4.0 United States License.

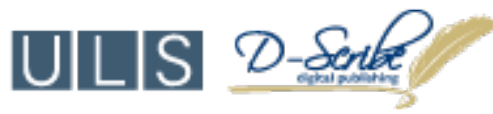

This journal is published by the University Library System, University of Pittsburgh as part of its D-Scribe Digital Publishing Program and is cosponsored by the University of Pittsburgh Press. 